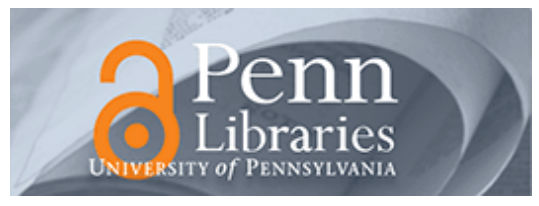

University of Pennsylvania ScholarlyCommons

1982

\title{
A New Proposal for Setting Intra-Company Transfer Prices
}

Rene Manes

Robert E. Verrecchia

University of Pennsylvania

Follow this and additional works at: https://repository.upenn.edu/accounting_papers

Part of the Accounting Commons, and the Business and Corporate Communications Commons

\section{Recommended Citation}

Manes, R., \& Verrecchia, R. E. (1982). A New Proposal for Setting Intra-Company Transfer Prices.

Accounting and Business Research, 12 (46), 97-104. http://dx.doi.org/10.1080/00014788.1982.9728794

This paper is posted at ScholarlyCommons. https://repository.upenn.edu/accounting_papers/82

For more information, please contact repository@pobox.upenn.edu. 
A New Proposal for Setting Intra-Company Transfer Prices

Disciplines

Accounting | Business and Corporate Communications 
College of Commerce and Business Administration

University of IIlinois at Urbana-Champaign

JuIy 5,1979

A NEW PROPOSAL FOR SETTING INTRA-COMPANY TRAIVSFER PRICES

Rene lianes, Professor, Department of Aecountancy

Robert E. Verrecchia, Assistant Professor, Department of Accountancy

\#582

Summary:

This paper proposes a method for establishing transfer prices based on the Shapley value. This is done by determining an agreed-upon weighting of factors of profitability within a firm, and then allocating the direct costing gross margin of the firm to its divisions by means of the factors and the Shapley value. 


$$
\begin{aligned}
& \text {; + . } \therefore \text {. } \\
& \because \ldots+\ldots \\
& \because: \quad . \quad \therefore .
\end{aligned}
$$

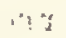

$$
\begin{aligned}
& \therefore
\end{aligned}
$$


The allocation of profit to divislons that results from this technique is a negotiated one only to the extent that those managerial factors most relevant to firm profit must flrst be agreed upon. Once reached, such an agreement eliminates periodic bargaining on transfer prices and embodies certaln properties of equity that are suggested by the Shapley value.

We shail also show the close relationship of the proposed allocation method to a widely used technique for the calculation of state corporation and franchise taxes, known as the "Massachusetts formula." This technique has grown out of the efforts of the states to take into account the complex causality of incone in a Federal System which permits corporations to domiclle in whatever state they choose while engaging in productive operations and marketing their goods wherever they choose.

\section{An IIlustration of the Procedure}

The procedure can perhaps best be explained by a numerical example. We assume a centralized planning body using a mathematical programming model to generate its forthconlng production schedule as follows:

$$
\begin{array}{r}
\operatorname{Max} \text { Prof1t }=2 x_{1}+4 x_{2}+5.5 x_{3}+8 x_{4} \\
\text { S.t (1) } x_{1}+x_{2}+1.2 x_{3}+2 x_{4} \leq 250 \\
\text { (2) } \\
x_{2}+1.5 x_{3}+2 x_{4} \leq 200 \\
\text { (3) } \\
x_{3}+1.5 x_{4} \leq 150
\end{array}
$$

and $a I I x$ i.s $\geq 0$

Assume that there are three major divisions in the firm and that constraints 1 to 3 represent the capacity limits of the divisions respectively. Product one, $x_{1}$ is a processed raw material which can be sold 
The transfer pricing problem has given rise to an extensive 1iterature, in which several ways have been suggested for determining the prices of intermediate products. ${ }^{1}$ These ways include systems based on:

1) Market prices

2) Marginal costs or variable costs wher the cost function is not known

3) Average costs plus or full cost plus, either actual or standard

4) Opportunity costs or shadow prices ${ }^{2}$

5) Negotiated prices, for which negotiatign might be initiated from any of the previous four methods.

In general there is no quarrel that when competitive market prices exist, these prices, adequately adjusted for internal economies of the integrated firm, should be the prices used to calculate divisional proflts. Difficulties arise, however, whenever there is no clear market price for an intermediate product and whenever 1ntegrated firms are required ${ }^{5}$ or whenever they elect to treat as profit centers thefr own divisions exchangtng intermediate products.

This paper will examine a method for establishing transfer prices based on the Shapley value. The approech is a form of variable cost "plus" pricing, in which the "plus" or, addition to variable cost, is determined according to an agreed-upon weighting of factors of profitability. In an ex ante planning process, the Shapley value will be used to distribute profit after the optinal schedule of production has been deterrined. Subsequent to this profit distribution, transfer prices will be calculated. A consequence of this approach is that the resulting transfer prices are neutral with respect to decision-making. 
Table 2

Profie Factors for $197 x$ Profit

\begin{tabular}{l|c|c|c|c} 
& Division & Division & Division & 3 \\
Profit Factors & 1 & 2 & Total for Firm \\
\hline Total Assets & $\$ 1550$ & $\$ 2000$ & $\$ 1200$ & $\$ 4750.00$ \\
\hline Total Payrol1 & 300 & 500 & 300 & 1100.00 \\
\hline Total Sales & $\$ 180$ & - & $\$ 2666.67$ & $\$ 2846.66$
\end{tabular}

We have no special reason for selecting these factors as most appropriate among those that are relevant to producing income. However, we do note that these profit factors are the same ones which states employ to assess the causal relationships for generating the lncome of corporations operating within their taxing jurfsdictions. 6

In Tabie 2. Total Assets are simpiy the debit side of the profit center's balance sheet, (we assume that these totals are the average of the opening and closting balances). Total Payroli includes not only direct labor as embodied in the $c_{j}$ 's, but also supervisory, sales, and administrative personel of the divisions. Ks such, each total payroll represents the responsibility of a division's management for the direction of its own personnel, for the training of that personnel, for unton relationships, ete. Finaliy Total Sales are the totals of ultimate dellveries by the firm to outside markets at freely competitive prices. Spectfically, the sales values which are given in Table 2 are those for the solution of our iliustrative example. 
by Division 1 at a competitive market price. Product $x_{2}$ is a semifinished good sold to manufacturers by Division 2 at a competitive market price. Products $x_{3}$ and $x_{4}$ are manufactured goods, $x_{3}$ being a low cost good and $x_{4}$ being a higher quality, wore carefully finlshed version of $\mathrm{x}_{3}$

Additionally, we know the per unit prices and variable costs of the $x_{j}$ 's as these costs are incurred in each division processing them.

\section{Table 1}

Prices and Variabie Costs

\begin{tabular}{|c|c|c|c|c|c|}
\hline & & $x_{1}$ & $x_{2}$ & $\mathrm{x}_{3}$ & $x_{4}$ \\
\hline $\mathrm{p}^{j}$ & & $\$ 8$ & $\$ 12$ & $\$ 20$ & $\$ 25$ \\
\hline \multirow[t]{3}{*}{ Variable Cost - Div. } & 1 & 6 & 5.5 & 3.50 & 4 \\
\hline & 2 & - & 2.5 & 7.00 & 8.50 \\
\hline & 3 & - & - & 4.00 & 4.50 \\
\hline Total Varlable Cost & & 6 & 8 & 14.50 & 17.00 \\
\hline Contribution Margin, & $c_{j}$ & 2 & 4 & 5.50 & 8.00 \\
\hline
\end{tabular}

And we also know, as any self respecting budget office would, the total assets and the payroll of the "profit centers" required to fmplement this schedule of production (refer to Table 2 ). 
total assets downwards by $x_{I}$ 's utilization of Division 1 's total capacity, 1.e., by $90 / 250$.

Table 2 Revised

Prof1t Factors for $197 \times$ Budget Adjusted to Eliminate Separate Market Transactions

\begin{tabular}{l|c|c|c|c} 
Prof1t Factors & Division 1 & Division 2 & Divia1on 3 & Total \\
\hline Total Assets & $\$ 1000$ & $\$ 2000$ & $\$ 1200$ & $\$ 4200$ \\
Total Payroll & 200 & 500 & 300, & 1000 \\
Total Sales & 0 & 0 & 2667 & 2667
\end{tabular}

\section{Calculation of Transfer Prices}

Now we proceed to the calculation of transfer prices. Firat we

observe from our 1ncome statement that the mark-up on product $x_{3}$ 1s approximately $38 \%$. Then we calculate for every coalition of divisions the gross margin which appertalns to that coalition of divisions given Its total varlable costs. (Refer to Table 3, Column 3). Next, using Table 2 Revised, we calculate for each coalition 1 ta proflt factor apportionment ratio in column 4. An Interpretation of this ratio is that 1 t represents the extent to whlch all of the possible coalitions of divisions utilize the full services of the firm and benefit from the integrated power of the f1rm. One can think of the existence of each of the separate sub-coalitions (1ncluding coalitions of a single division) as representative of groups "going it alone," 1.e., groups obliged to buy goods and services of all sorts outside of the firm and thus forced to share profits with outsiders. The grand coalition of all divisions is the fully Integrated flrm whllch benefits from the total income producing power of the firm. 7 
Profit $\$ 913.33$

$x_{1} 90$ undts

$x_{3} 1331 / 3$ units

$\mathrm{x}_{7} \quad 16 \quad 2 / 3$ units [slack of Div. 3]
Shadow Prices

Division 1 Capacity $\$ 2.000$

Division 2 Capac1ty 2.067

Division 3 Capacity

A pro forms income statement for this budgeted schedule of production follows

Pro Forma Income Statement for $197 \times$ Budget

\begin{tabular}{|c|c|c|c|c|c|}
\hline . & & \multicolumn{2}{|c|}{$x_{1}$} & $x_{3}$ & Total \\
\hline Sales Revenue & & $\$$ & 720 & $\$ 2666.66$ & $\$ 2846.66$ \\
\hline Less & Division 1 & & 540 & 466.66 & 1006.66 \\
\hline Cost of & Division 2 & & - & 933.33 & 933.33 \\
\hline Goods Sold: & Division 3 & & - & 533.33 & 533.33 \\
\hline Sub & Total & & 540 & 1933.33 & 2473.33 \\
\hline Gross Margin & & & 180 & $\$ 733.33$ & $\$ 913.33$ \\
\hline
\end{tabular}

Only one adjustment to our data remains to be made before we calculate internal transfer prices. Wherever competitive market prices exist, and sales are made at those prices in such a way that we can completely disengage those transactions from the rest of the company's Income statement and from Table 2 (The Table of Prof1t Factors), we shall do so. Specifically, for our problem we make this adjustment for $x_{1}$, the revenues and costs of which can be eliminated easily from the income statement. We also must adjust Table 2 to eliminate $x_{1}$ sales and payroll costs from Divison 1 data and to revise Division 1 total property so that it will represent only those assets comitted to $x_{3}$. Here, the "bugaboo" of cost allocation must be faced. We do this by adfusting 
Table 3

Divisional Coal1titions, Apportionment Ratios and Profits

\begin{tabular}{|c|c|c|c|c|c|}
\hline $\begin{array}{l}\text { Col (1) } \\
\text { Coalition } \\
\text { of } \\
\text { Division }\end{array}$ & $\begin{array}{c}\operatorname{Col}(2) \\
\therefore \text { Varlable } \\
\therefore \text { Costs }\end{array}$ & $\begin{array}{l}\text { Mark-up } \\
\text { Col (2.) } \\
=338 \%\end{array}$ & Profit Factor Apportionment & Ratio & $\begin{array}{c}\text { Col (5) } \\
\text { Adfusted } \\
\text { Coalition } \\
\text { Profit } \\
\text { Col (3) x } \\
\operatorname{col}(4)=5\end{array}$ \\
\hline 1 & $\$ 466.66$ & 今 177 & $\frac{1}{3}\left\{\frac{1000}{4200}+\frac{200}{1000}+\frac{0}{2667}\right\}=$ & .146 & $\$ 26$ \\
\hline 2 & 933.33 & 354 & $\frac{1}{3}\left\{\frac{2000}{4200}+\frac{3500}{1000}+\frac{0}{2667}\right\}=$ & .327 & 116 \\
\hline 3 & 533.33 & 202 & $\frac{1}{3}\left\{\frac{1200}{4200}+\frac{300}{1000}+\frac{2667}{2667}\right\}=$ & .526 & 106 \\
\hline $1+2$ & 1400.00 & 531 & $\frac{1}{3}\left\{\frac{3000}{4200}+\frac{700}{1000}+\frac{0}{2667}\right\}=$ & .470 & 249 \\
\hline $1+3$ & 1000.00 & 379 & $\frac{1}{3}\left\{\frac{2200}{4200}+\frac{500}{1000}+\frac{2667}{2667}\right\}=$ & .675 & 256 \\
\hline $2+3$ & 1466.67 & 556 & $\frac{1}{3}\left\{: \frac{3200}{4200}+\frac{800}{1000}+\frac{2667}{2667}\right\}=$ & .837 & 465 \\
\hline $1,2+3$ & 1933.33 & 733 & $\frac{1}{3}\left\{\frac{4200}{4200}+\frac{1000}{1000}+\frac{2667}{2667}\right\}=$ & 1.000 & 733 \\
\hline
\end{tabular}

F1nally, using Colum 5, Adjusted Coalition Proftt (ACP), we allocate the $\$ 733$ profit from intermediate product sales of $x_{3}$ to divisions using the Shapley. value. ${ }^{8}$ Profit allocstion to exch division 18:

$\begin{aligned} & \text { Share of Profit } \\ & \text { ocated to Division }\end{aligned}=\sum_{S \in N} \frac{(s-1) !(n-s) !}{n !}(A C P(S)-\operatorname{ACP}(S-\{1\}))$, where $s$ is the number of divislors in coalition $S$ and $n$ is 3 , the total number of divislons. The results are presented in Table 4. 
Table 4

\section{Calculation of Transfer Prices}

\begin{tabular}{|c|c|c|c|c|c|}
\hline & $\begin{array}{l}\text { Col } 1 \\
\text { Shapley Proftt } \\
\text { Allocation }\end{array}$ & $\begin{array}{c}\text { Col } 2 \\
\text { Per Untt } \\
\text { Divisional Profit } \\
\text { Col (1) } \div 1331 / 3 \\
\text { Units }\end{array}$ & $\begin{array}{l}\text { CoI } 3 \\
\text { Vari- } \\
\text { able } \\
\text { Cost } \\
\text { per Unit }\end{array}$ & $\begin{array}{l}\text { Col } 4 \\
\text { Carried Forward } \\
\text { Cost from Col. } 5 \\
\text { of Previous } \\
\text { Division }\end{array}$ & $\begin{array}{l}\text { Col } 5 \\
\\
\text { Transfer } \\
\text { Prlce }\end{array}$ \\
\hline DIv I & $\$ 145.17$ & $\$ 1.09$ & $\$ 3.50$ & $\$ 0$ & $\$ 4.59 /$ unit \\
\hline 2 & 294.66 & 2.21 & 7.00 & 4.59 & 13.80 \\
\hline 3 & & 2.20 & 4.00 & 1.3 .80 & 20.00 \\
\hline Total & 733.00 & & & & \\
\hline
\end{tabular}

Comments About the procedure

Th1s method of setting transfer prices has been offered and explained in the framework of a mathematically programmed budget solution. However, note that a mathematically programmed budget is not at all necessary since the same calculations could have been made for a production schedule generated by clever Intuition or by gross incompetence (albeit, for a more or less diminished profit). Putting the calculation in the framework of an 1.p. model does illustrate that this transfer pricing method in no way Interferes with optimal decision making.

Behaviorly we do not see how 1 t suffers from any of the many complaints levied at other transfer pricing procedures. Unllke an opportunfty cost or shadow price approach, it does not reward bottlenecks and penalize long range provistons of capacity to the benefit of short run maximizers. It Is neither biased in favor of the buyer (be he nonopolist) or in favor of 
the seller (be he monopolist). As Roth and Verrecchia have polnted out (and assuming that agreement can be arrived at regarding factors contributing to profit) the Shapley value provides a one-time negotiated procedure which is equitable. Although a division manager might be induced to overstate the portion of his division"s assets and payroll to be devoted to the production of intermediate products, there is every reason, In fact, to him to use labor and capital as efflciently as possible, since profit can only be enjoyed if a manager helps to create it. Some readers will argue that too heavy a weighting has been accorded to sales. That may very weil be. If, in any particular case it proves to be so, managenent must then decide on a priori, negotiated basis how best to weight seling effort, or personnel mangement, or the operation and maintenance of plants. For firms which wish to use an RoI measure of the management of profit centers, the Shapley value allocation makes a profit attribution to assets such that an Ror calculation can readily be made.

Al1 In ail, if we are willing to assume the admittedly difficult task of specifying those responsibilities of managenent which cause profit, l.e., the "factors of profitability", then we have a technique which does the following. It supplements decision making without interfering in it; it recognizes the need for measuring relevant variable costs but attributes proftt to centers in a manner compatible with top management's desire to measure performance on the basis of multiple factors, such as return on investment, personnel management and market results. 


\section{Footnotes}

is sejective Iist of refezences on the subject must start wh reference to managment science and economic 11terature on the subject such as: J. Birshliefer, "On the Economics of Tranfer Pricing," The Journal of Business, Vol. 29, 1956 and "Economics of the Divistonalized Fimm, The Journal of Business, Vol. 30, 1957 ; M. Shubik, "Incentives, Decertralized Control, the Assigneric of Jolat Costs and "ransfer Prictng, "Mnagement Science,

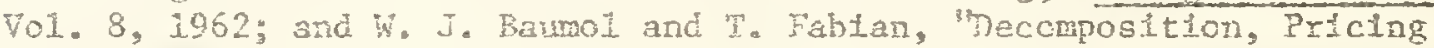
for Decentralizarion and Extemal Economies," Mangement Sejence, Sept. 1964, pp. 1-3I. Among eariler papers in accounting on the subject refer to $\gamma_{1}$. Beman, Ir., "Pricing Intracompany mransfers," The Accounting Review, Juiy 1959; D, Solomons, bivisional Per formance: Measurement and Control, 2. D. Irwin, Inc., I965, Chap. 6 \& Appendix A; H. Dopuch and D. Drake, "Accounting Imp1.1cations of a Mathematical Progtaming Approach to the Transfer Price Problen," The Journal of Accounting Research, Spring 1964; J. Ronen and $C_{0}$. Mcknney III, "Transfer Pric1ng to Divisional Atronomy," The Jourara of Accountlng Research, VIII, Spring 1970 ; and $R$. Abdel-Rhalik and $E_{0}$ Lusk, "Transfer Pricing: A Synthesis," The Accounting Review, January 1974, pP. 8-23.

21. Onsi, "A Transfer Pricing Systen Based on Opportunity Cost," The Accounting Rev1ew, JuIy 1970, pp. 535-43 and R. Mares, "Birch Paper Company Revisited: An Exercize In Transfer Pricing," The Accounting Review, July 2970 , pp. 640-43.

${ }^{3}$ G. Shilinglaw, Managerial Cost Accounting, 4 th Ed, R. D. Irwin, Inc., 1977, Chap. 26.

4P. W. Cook, Ir., "Decentraituation and the Transfer Price Probleng" The Journal of Business, XXVI, 1955; J, R. Could, "Internal Pricing in Term When There Are Costs of Using an Outside Market," The Joumal of Bustness, January 1954.

5esearch on transfer priring has of cen criticized flun whth highiy centralized planning brogets for enforclng transer prlces artficially, but it has rot taken lnto account how often transfer prices for intermediate products are regulred for institutlonal reasons: such as International boundarles, foint ventures, regulatory comissions, historical combirations and acquisitions in which separate corporate entitues are malntained, the existence of minority intercsts in consolidated systems, etc. Refer to A. L. Thomas, "Transfer Prices of the Multinational Firm: When Will They Be Arb1trary," Information Dectston Making, 2nd Ed., A Rappaport, 3975 .

6. Oldwan and F. P. Scroetrle, State ano Local Taxes and Finance, The Foundation Press, 1974, Chapter 5, pp. 550-586. Twenty six states use three factor formulas to assess state corporation ircome and franchise taxes, i.e., 
$\frac{1}{3}\left\{\frac{\text { In State Property }}{\text { Total Property }}+\frac{\text { In State Property }}{\text { Total Payroli }}+\frac{\text { In State Sales }}{\text { Total SaIes }}=\right.$ Apportioniment Ratio

A corporation's tax payment is then calculated to be a product of its total corporate-wide income, 1 to apportiontent, find the tax rate, as each are deffned by the taxing furisatction, e.g., [Total Corporate Income $x$ Tax Rate $x$ Apportiontent Ratiol. Another ten or more states use variations on the three-factor "hassachusets formilu" in an attempt to exact revenue from corporations which, for example, avold doing bustness in a state by setting up only a sales outlet lis that state, or avold having income in a state by transînerring manufactured goods out of its factories in the state at cost.

7

Note that adfusted coalition profit is frcteas ingly profitabie to the scale or degree of integration, $1 . e$, that it is superaditive, although this property is not a necessary one. Hote also that one simple, and we belleve too simple, way to establish transfer prices would be to attribute the everage markoup to each diviston. Then the three divisions would share profit in accordance thith the first three numbers in column 3 of rable 3 .

Sin the last ten years several articles have detained the application of the Shapley value to problems of public finance and of accounting. The most specific instructions are to be fourd in D. Itensen, "A Class of Mutually Satisfactory Allocations," The Accomting Review, Oct. 1977, p. 842-856 and in S. S. Famien, W. A. Marien and J. T. Ischirhart, "The lise of Core Theory in Evaluating Joint Cost Allocetion Schenes," The Accounting Review, July 1977, pp. 6i6-627. Refer also to E. T. Loehran and A. B. Whinston, "A New theory of Prichng and Decision Making in Public Investment," The Bell Jourmi of Economics and Management Science, Autum 1971, PP. 606-623; and J. L. Callen, "Financial Cost Allocation: A Geme Theorecic Approach," The Accounting Review, April 1978, pp. 303-308.

${ }^{9}$ A. E. Roth and R. E. Verrecchia, "The Shapley Value as Applied to Cost Allocation: A Reinterpretation," forthcoming in The Journal of Accounting Research, and R. E. Verrecchia, "A Question of Equity: Use of the Shapley Value to Allocate State and Local Income and Franchise Tares." University of Illinofs Col. of Commerce and Bus. Admin., Working Paper 569. 